\title{
Penurunan Kadar IL-1 $\beta$ Makrofag Terpapar Agregat Bakteri Actinomycetemcomitans setelah Pemberian Minyak Atsiri Temu Putih
}

\author{
Juni Handajani*, Siti Fatimah*, Ristini Asih ${ }^{* *}$, dan Antinah Latif** \\ *Bagian Biologi Mulut, Fakultas Kedokteran Gigi, Universitas Gadjah Mada, Yogyakarta, Indonesia \\ ** Program Studi Ilmu Keperawatan Gigi, Fakultas Kedokteran Gigi, Universitas Gadjah Mada, Yogyakarta, Indonesia \\ *JI Denta No 1 Sekip Utara Yogyakarta, Indonesia; e-mail: junihandajani@yahoo.com
}

\begin{abstract}
ABSTRAK
Kunci regulator terhadap respons inflamasi diketahui melalui aktivasi interleukin-1 $\beta$ (IL-1 $\beta$ ). Makrofag merupakan sel fagosit mononuklear berperan dalam sistem imun innate dan adaptif. Sitokin yang disekresikan makrofag sebagai respons terhadap patogen antara lain IL-1, IL-6, IL-12, TNF- $\alpha$, dan chemokine. Minyak atsiri temu putih (Curcuma zedoaria Rosc.) diduga memiliki efek anti inflamasi. Tujuan penelitian ini adalah untuk mengetahui kadar IL-1 $\beta$ pada makrofag terekspose aggregat bakteri actinomycetemcomitans setelah pemberian minyak atsiri temu putih. Subjek penelitian adalah 10 ekor tikus Wistar jantan yang dibagi menjadi 2 kelompok (perlakuan dan kontrol), masing-masing kelompok terdiri atas 5 ekor. Kelompok perlakuan diberi minum minyak atsiri temu putih dosis $30,6 \mu \mathrm{l} / \mathrm{ml}$ dan kelompok kontrol diberi aquabides selama 14 hari. Gingiva anterior rahang bawah tikus diolesi A.actinomycetemcomitans sebanyak $100 \mu \mathrm{l}$ dalam CMC $2 \%$ pada hari ke-7 setelah pemberian minum bahan uji dan kontrol selama 7 hari. Pada hari ke-15, tikus pada masingmasing kelompok dianestesi lalu makrofag dikoleksi dari cairan peritoneal. Kadar IL-1 $\beta$ makrofag diukur menggunakan ELISA kit (R\&D Systems, USA), selanjutnya data dianalisis menggunakan uji-t. Hasil penelitian menunjukkan terdapat penurunan kadar IL-1 $\beta$ setelah perlakuan. Perbandingan kelompok perlakuan dan kontrol menunjukkan perbedaan bermakna $(p<0,05)$. Disimpulkan bahwa minyak atsiri temu putih kemungkinan memiliki efek anti inflamasi melalui penurunan kadar IL-1 $\beta$ makrofag.
\end{abstract}

Maj Ked Gi Ind. Desember 2015; 1(2): 130 - 135

Kata kunci: minyak atsiri temu putih (Curcuma zedoaria Rosc.), makrofag, kadar IL-1 $\beta$

\begin{abstract}
IL-1 $\beta$ level of macrophage exposed to $A$. actinomycetemomitans decreases after administration Curcuma Zedoaria volatile oil. Activation of interleukin-1 $\beta(I L-1 \beta)$ is a key regulator of the inflammatory response. Macrophage is a phagocytic mononuclear cell that plays an important role in innate and adaptive immune response. The cytokine secreted by macrophages in response to pathogen are IL-1, IL-6, IL-12, TNF- $\alpha$ and chemokine. Curcuma zedoaria volatile oil may have anti inflammation effect. The aim of this study was to investigate IL-1 $\beta$ level of macrophage exposed to A. actinomycetemcomitans after administration Curcuma zedoaria volatile oil. The subjects were 10 male Wistar rats, which divided into two groups (treatment and control), each group 5 rats. In the treatment group, 30,6 $\mu$ // $\mathrm{ml}$ Curcuma zedoaria volatile oil was administered per oral for 14 days and the control group used aquabidest. In the $7^{\text {th }}$ days, $100 \mu \mathrm{l}$. actinomycetemcomitans in CMC 2\% were applied on the anterior gingival mandible for 7 days. Rats were anesthetized in the $15^{\text {th }}$ days then macrophage was collected from peritoneal. Interleukin- $\beta$ level of macrophage was measured using ELISA kit (R\&D Systems, USA). Data were analyzed using t-test. The result showed IL-1 $\beta$ level decreased after treatment. The comparison between treatment and control was significant difference $(p<0.05)$. It can be concluded that Curcuma zedoaria volatile oil may have anti inflammation effect through reducing the IL-1 $\beta$ level of macrophage.
\end{abstract}

Maj Ked Gi. Ind. Desember 2015; 1(2): 130 - 135

Keywords: Curcuma zedoaria volatile oil, macrophage, IL-1 1 level

\section{PENDAHULUAN}

Makrofag merupakan satu dari tiga tipe sel fagosit pada sistem imun dan terdistribusi secara luas pada jaringan tubuh. Sel ini memegang peranan penting pada imunitas innate dan adaptive serta diketahui sebagai bentuk mature dari monosit. Monosit beredar dalam sirkulasi dan berdiferensiasi secara terus-menerus menjadi makrofag. Sel makrofag tersebut akan menetap di jaringan (histiosit). Makrofag diketahui lebih aktif dalam melakukan fagositosis dibandingkan monosit dan lebih banyak memiliki granula dengan kandungan enzim hidrolitik. ${ }^{1}$ Makrofag dan neutrofil merupakan garis pertahanan pertama sistem imun innate terhadap mikroorganisme dan berperan penting untuk mengontrol infeksi bakteri. ${ }^{2}$ 
Mikroorganisme seperti bakteri yang berpenetrasi ke permukaan epithelial tubuh, pertama kali akan dihadapi oleh sel maupun molekul yang berperan pada respons imun innate. Fagositosis makrofag bertanggungjawab sebagai pertahanan terhadap bakteri, atau dapat diartikan reseptor permukaan memiliki kemampuan untuk mengenali maupun berikatan dengan komponen permukaan bakteri. Ikatan molekul bakteri dengan reseptor akan memicu makrofag untuk menelan bacterium juga menginduksi sekresi molekul aktifbiologis. Makrofag yang teraktivasi tersebut akan mensekresikan protein yang dilepaskan oleh sel akibat teraktivasi atau yang disebut sitokin. Makrofag terutama berperan dalam fagositosis tahap infeksi kronis serta memiliki fungsi sebagai Antigen Presenting Cell (APC) kepada limfosit. Proses ini diperlukan untuk inisiasi respons imun adaptif dari host. Sitokin dan kemokin yang dilepaskan oleh makrofag sebagai respons terhadap terhadap komponen bakteri akan menginisiasi proses inflamasi.3,4

Sitokin merupakan protein berukuran kecil $(\sim 25 \mathrm{kDa})$ yang dilepaskan oleh berbagai sel sebagai respon terhadap aktivasi stimulus dan induksi respon melalui ikatan terhadap respon spesifik. Sitokin tersebut dapat beraksi secara autocrine sehingga mempengarui lingkungan pada sel yang melepaskannya, atau secara paracrine dengan berpengaruh terhadap sel lain di sekitarnya.

Beberapa sitokin juga dapat beraksi secara endocrine yang berpengaruh terhadap lingkungan sel di sekitarnya meskipun kemampuannya tergantung saat memasuki sirkulasi maupun waktu paruhnya (half-life). Makrofag memiliki kemampuan mensekresikan beberapa sitokin sebagai respons terhadap patogen antara lain interleukin 1(IL-1) interleukin-6 (IL-6), inteleukin 12 (IL-12), Tumor Necrosis Factor- $\alpha$ (TNF- $\alpha$ ) dan kemokin IL-8. ${ }^{4,5}$

Temu putih (Curcuma zedoaria Rosc.) telah banyak diketahui khasiatnya baik secara tradisional maupun untuk pengobatan kanker. Beberapa khasiat temu putih antara lain sebagai bahan utama jamu sesudah melahirkan, juga sebagai stomatikum, karminativum, tonikum, penawar gigitan ular, serta pengobatan luka dan ulser. Rimpang dan minyak atsiri temu putih mengandung sejumlah senyawa seskuiterpen termasuk kurkumin dan derivat- derivatnya. Minyak atsiri rimpang temu putih berupa cairan kental kuning emas dengan kandungan 1) monoterpen hidrokarbon (a-pinen, D-kamfen), monoterpen alkohol (D-borneol), monoterpen keton (D-kamfor), monoterpenoksida dan sineol, dan 2) seskuiterpen golongan: bisabolan, eleman, germakran, eudesman, guaian dan spirolakton. ${ }^{6}$ Kandungan minyak atsiri pada Curcuma zedoaria juga dilaporkan berupa $1,8 \mathrm{cineol}(18.5 \%)$, cymene (18.42\%), a-phellandrene (14.9\%).

Beberapa hasil penelitian mengemukakan bahwa komponen ekstraksi metanolik temu putih yang berefek sebagai anti inflamasi adalah furanodiene dan furanodienone. Penelitian tersebut dilakukan dengan induksi inflamasi pada telinga tikus. ${ }^{7}$ Fraksi polisakarida temu putih dosis $1 \mathrm{mg} / \mathrm{ml}$ diketahui dapat meningkatkan aktivitas fagostosis sel makrofag peritoneal RAW 264.7. Daya antimikroba ekstrak temu putih pernah diteliti oleh Bugno pada dosis $100 \mathrm{mg} / \mathrm{ml}, 250 \mathrm{mg} / \mathrm{ml}, 500$ $\mathrm{mg} / \mathrm{ml}$ dan $1000 \mathrm{mg} / \mathrm{ml}$ terhadap Streptococcus mutans, Enterococcus faecalis, Staphylococcus aureus dan Candida albicans. ${ }^{9}$

Aktivitas anti inflamasi minyak atsiri temu putih (Curcuma zedoaria, Rosc.) terhadap udem buatan pada tikus putih betina galur Wistar diketahui pada dosis $400 \mathrm{mg} / \mathrm{kg} \mathrm{BB} .{ }^{10}$ Pemberian minum minyak atsiri temu putih setiap hari sebanyak dosis $30,6 \mu \mathrm{l} / \mathrm{ml}$ selama 14 hari menunjukkan peningkatan aktivitas fagositosis neutrofil pada tikus putih yang diinduksi Aggregatibacter actinomycetemcomitans. ${ }^{11} \mathrm{Pe}-$ nelitian Naz dkk. ${ }^{12}$ menyebutkan pada dosis minyak atsiri temu putih $28 \mathrm{mg} / \mathrm{ml}$ atau setara dengan 30,6 $\mu \mathrm{l} / \mathrm{ml}$, telah menunjukkan daya antimikroba temu putih terhadap Bacillus subtilis, Bacillus macerans, Bacillus licheniformis dan Azotobacter pada konsentrasi berkisar 4-28 mg/ml in vitro. Minyak atsiri temu putih juga dapat dapat menurunkan inflamasi gingiva ditandai dengan penurunan ekspresi CD4+. ${ }^{13}$ Penelitian selanjutnya juga menyebutkan opsonisasi serum mampu meningkatkan aktivitas fagositosis sel makrofag yang telah diinduksi minyak atsiri temu putih. ${ }^{14}$

Aggregat bakteri actinomycetemcomitans atau Actinobacillus actinomycetemcomitans (Aa)sebagai bakteri Gram-negatif fakultatif non-motil berbentuk 
batang dan termasuk kategori komensal di rongga mulut. Bakteri tersebut dapat diidentifikasi dari plak gigi, poket periodontal maupun sulkus gingiva. Keadaan infeksi endocarditis, brain abcesses dan penyakit periodontal diduga berkaitan dengan bakteri Aa. Induksi bakteri maupun produknya dapat menstimulasi keadaan inflamasi. Keadaan inflamasi jaringan mukosa rongga mulut akibat infeksi bakteri akan menginisiasi untuk aktivasi sel-sel pertahanan rongga mulut. ${ }^{15}$ Permasalahannya adalah belum diketahui kadar IL-1 $\beta$ makrofag terpapar $A$. actinomycetemcomitans setelah pemberian minyak atsiri temu putih (Curcuma zedoaria Rosc.) sehingga diharapkan hasil penelitian ini dapat memberi informasi ilmiah salah satu mekanisme anti inflamasi minyak atsiri temu putih.

\section{METODE PENELITIAN}

Penelitian ini termasuk kategori penelitian eksperimental murni yang telah dilakukan di Laboratorium Penelitian dan Pengujian Terpadu - Universitas Gadjah Mada (LPPT-UGM). Persetujuan etik penelitian diperoleh dari Tim Etik Penelitian Fakultas Kedokteran Gigi Universitas Gadjah Mada Yogyakarta melalui surat No.301/ KKEP/FKG-UGM/EC/2012. Rimpang temu putih (Curcuma zedoaria (Berg.) Roscoe) dideterminasi di Bagian Biologi Farmasi Fakultas Farmasi UGM (No.BF/189/Ident/Det/VI/2012). Destilasi minyak atsiri temu putih dilakukan di LPPT-UGM dengan hasil $3 \mathrm{ml}$ minyak atsiri konsentrasi 100\% diperoleh dari rimpang temu putih sebanyak 2833 gram.

Subjek penelitian sebanyak 10 ekor tikus Wistar jenis kelamin jantan usia 3 bulan dibagi menjadi 2 kelompok, 5 ekor tikus pada masingmasing kelompok. Pemberian minum minyak atsiri temu putih dosis $30,6 \mu \mathrm{l} / \mathrm{ml}$ dilakukan pada kelompok perlakuan dan kelompok kontrol diberi minum aquabides sebanyak $1 \mathrm{ml}$ selama 14 hari.

Bakteri A. Actinomycetemcomitans diperoleh dari Laboratorium Mikrobiologi, Fakultas Kedokteran Hewan Universitas Gadjah Mada. Bakteri dengan konsentrasi $\pm 1 \times 10^{9} \mathrm{sel} / \mathrm{ml}$ dalam keadaan hidup dicampurkan dengan Carboxymethy Cellulose Sodium (CMC) (MP Biomedical, Inc) konsentrasi $2 \%$. Pembuatan campuran A. actinomycetemcomitans dalam CMC 2\% dilakukan setiap pagi hari pada saat akan dioleskan. Pengolesan campuran $A$. actinomycetemcomitans dalam CMC $2 \%$ sebanyak $100 \mu$ dilakukan selama 7 hari pada gingiva anterior rahang bawah baik kelompok perlakuan maupun kontrol.

Prosedur selanjutnya dilakukan koleksi makrofag pada hari ke-15 dengan diawali anestesi menggunakan Ketamin hidroklorida 10\% $\left(\right.$ Ketami $^{\circledR}$ ) dosis $100 \mathrm{mg} / \mathrm{kg}$ berat badan secara intramuscular. Metode koleksi makrofag dari peritoneal telah dipublikasikan sebelumnya oleh Handajani ${ }^{14}$ dengan cara pembuatan irisan kecil pada perut subjek sampai tampak peritoneum. Medium RPMI yang mengandung 2\% FBS disuntikkan sebanyak $10 \mathrm{ml}$ ke dalam rongga peritoneum lalu ditunggu selama 2 menit sambil ditekan secara perlahan. Cairan peritoneal diambil dengan aspirasi dari rongga peritoneum di daerah kuadran kiri bawah abdomen. Aspirat yang diperoleh selanjutnya ditampung dalam tabung lalu disentrifugasi pada $1.200 \mathrm{rpm}$, $4^{\circ} \mathrm{C}$ selama 10 menit. Supernatan dibuang lalu pelet ditambahkan $3 \mathrm{ml}$ medium RPMl sebanyak $3 \mathrm{ml}$.

Penghitungan viabilitas sel dilakukan dengan menghitung jumlah sel yang telah diwarnai larutan trypan blue dan menggunakan hemocytometer. Makrofag yang viable (hidup) terlihat bening atau tidak berwarna karena trypan blue tidak dapat memasuki membran sel sedangkan makrofag mati akan menyerap warna sehingga tampak berwarna biru. ${ }^{16}$

Prosedur selanjutnya pelet diresuspensi dengan medium RPMI sehingga diperoleh suspensi makrofag dengan kepadatan sebanyak $2,5 \times 10^{6} \mathrm{sel} / \mathrm{ml}$. Penanaman suspensi sel dalam microplate 24 well yang dasar platenya telah diberi coverslip bulat. Setiap sumuran diisi suspensi sel sebanyak $200 \mu \mathrm{l}\left(2,5 \times 10^{5}\right.$ sel). Microplate diinkubasi dalam inkubator suhu $37^{\circ} \mathrm{C} 5 \% \quad \mathrm{CO}_{2}$ selama 30 menit lalu ditambahkan media RPMl sebanyak $1 \mathrm{ml}$ tiap sumuran, selanjutnya inkubasi lagi selama 2 jam. Sel dicuci dengan RPMI 2 kali kemudian ditambahkan medium RPMI sebanyak $1 \mathrm{ml}$ tiap sumuran dilanjutkan inkubasi lagi selama 24 jam pada suhu $37^{\circ} \mathrm{C}$. Pengukuran kadar IL-1 $\beta$ makrofag menggunakan ELISA kit (R\&D Systems, USA). Absorbansi dibaca menggunakan ELISA reader 
pada $450 \mathrm{~nm}$. Kadar IL-1 $\beta$ ditentukan melalui intrapolasi dari kurve standar.

\section{HASIL PENELITIAN}

Hasil perhitungan viabilitas menunjukkan 95\% sel viable (hidup). Hasil rerata dan standar deviasi kadar IL-1 $\beta$ makrofag $(\mathrm{pg} / \mathrm{ml})$ setelah pemberian minum minyak atsiri temu putih dan kontrol selama 14 hari ditampilkan pada Gambar 1.

\section{PEMBAHASAN}

Makrofag merupakan sel fagosit yang berperan menelan (engulf) dan melakukan digesti (digest) debris seluler, substansi asing maupun mikroorganisme. Sel tersebut berperan penting pada imunitas innate juga membantu menginisiasi mekanisme spesifik pada imunitas adaptive. Pada proses inflamasi, makrofag memiliki 3 fungsi utama yaitu antigen presentation, fagositosis, dan immunomodulasi melalui produksi berbagai sitokin

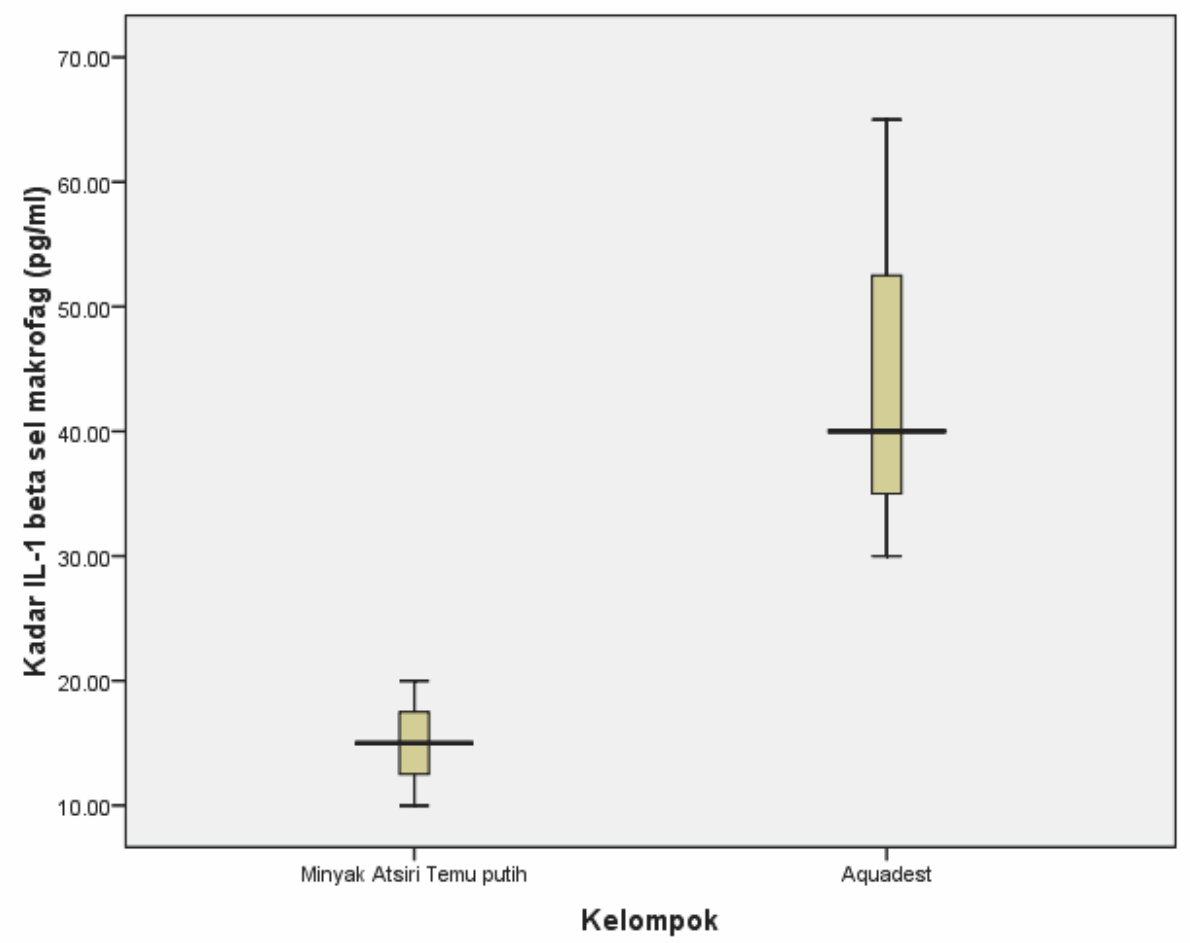

Gambar 1. Rerata dan standar deviasi kadar IL-1 $\beta$ makrofag setelah pemberian minyak atsiri temu putih (perlakuan) dan aquades (kontrol)

Hasil perhitungan normalitas data kadar IL-1 $\beta$ makrofag menggunakan Shapiro-Wilkmenunjukkan $\mathrm{p}>0,05$ dan hasil uji varians menggunakan Levene's test menunjukkan $p=0,101(p>0,05)$, hal ini berarti data terdistribusi normal dan varians data kedua kelompok sama. Selanjutnya dilakukan uji t tidak berpasangan (independent t-test) pada kemaknaan $95 \%$ dengan hasil $p=0,049$. Hasil tersebut dapat diinterpretasikan bahwa pemberian minum minyak atsiri temu putih selama 14 hari menunjukkan bermakna menurunkan kadar IL-1 $\beta$ makrofag apabila dibandingkan kontrol (aquades). dan growth factor. Makrofag juga memiliki peran penting pada inisiasi, maintenance dan resolusi inflamasi. Sel tersebut dapat diaktifkan maupun dinonaktifkan dalam proses inflamasi. Sinyal aktivasi meliputi sitokin (interferon gamma, granulocyte-monocyte colony stimulating factor, dan tumor necrosis factor alpha), lipopolisakarida bakteri, matriks protein ekstraseluler, mediator kimiawi lainnya. Penghambatan inflamasi melalui deaktivasi mediator dan sel efektor inflamasi yang memungkinkan host untuk memperbaiki jaringan. ${ }^{17}$ 
Hasil penelitian menunjukkan kadar IL-1 $\beta$ kelompok kontrol lebih tinggi dibandingkan kelompok perlakuan (Gambar 1). Hal ini menunjukkan induksi aggregat bakteri actinomycetemcomitans mampu meningkatkan kadar IL-1 $\beta$ pada reaksi inflamasi. ${ }^{18}$ Pada hasil perhitungan statistik diperoleh berbeda bermakna perbandingan kelompok kontrol dengan perlakuan $(p<0,05)$.

Hasil kadar IL-1 $\beta$ kelompok perlakuan lebih rendah dibandingkan kontrol diduga berkaitan dengan telah terjadinya penurunan keadaan inflamasi. Mekanisme penurunan inflamasi kemungkinan karena peran minyak atsiri temu telah meningkatkan (menstimulasi) respons imun tubuh melalui pemberian minum selama 14 hari sehingga pada saat bakteri dipaparkan, aktivasi makrofag telah meningkat untuk melakukan fagositosis. Hasil ini sejalan dengan penelitian sebelumnya bahwa minyak atsiri temu putih meningkatkan aktivitas fagositosis baik makrofag maupun neutrofil. ${ }^{11,14}$ Peningkatan respons imun tubuh kelompok perlakuan diduga karena minyak atsiri temu putih efektif untuk meningkatkan produksi TNF-a. Protein tersebut mampu mengaktivasi makrofag untuk melakukan proses penelanan mikroorganisme dengan cara memacu pathway respiratory burstdependent dan NO-dependent killing. ${ }^{19}$

Mekanisme lain yang diduga menyebabkan lebih rendahnya kadar IL-1 $\beta$ kelompok perlakuan dibandingkan kontrol yaitu minyak atsiri temu putih adalah induksi pelepasan TGF- $\beta 1$. Peran TGF- $\beta 1$ diketahui dapat menghambat aksi sel T antara lain menghambat sekresi interleukin-1 dan IL-2-dependent proliferasi sel $\mathrm{T}$, menghambat aktivasi sel T helper dan sel T sitotoksik. ${ }^{20}$ Hasil ini diperkuat dengan pemeriksaan histologis jaringan gingiva kelompok perlakuan setelah pemberian minum minyak atsiri temu putih yang menunjukkan ekspresi $\mathrm{CD}^{+}{ }^{+}$positif lemah di lamina propria. ${ }^{13}$ Sesuai hasil penelitian Seymour et al. ${ }^{21}$ bahwa terdapat penurunan sel $\mathrm{CD}^{+}$pada jaringan gingiva yang sudah mengalami penyembuhan (recovery) setelah inflamasi. Hasil penelitian ini dapat disimpulkan bahwa minyak atsiri temu putih kemungkinan memiliki efek anti inflamasi melalui penurunan kadar IL-1 $\beta$ makrofag.

\section{UCAPAN TERIMA KASIH}

Penulis menyampaikan terimakasih kepada Fakultas Kedokteran Gigi - Universitas Gadjah Mada yang telah membiayai penelitian ini melalui Dana Masyarakat.

\section{DAFTAR PUSTAKA}

1. Abbas AK, Lichtman AH, Phillai S. Cellular and molecular immunology. $7^{\text {th }}$ ed. Philadelphia: Elsevier; 2013. H. 50-5.

2. Samaranayake L. Essential microbiology for dentistry. $4^{\text {rd }}$ ed. Hongkong: Elsevier; 2012. $\mathrm{H}$. 100-15.

3. Janeway CA Jr, Travers $P$, Walport $M$. Immunobiology: The immune system in health and disease. $7^{\text {th }}$ ed. New York: Garland Science; 2008. H. 2.19-2.20.

4. Abbas AK, Lichtman AH. Basic immunology: functions and disorders of the immune system. $3^{\text {rd }}$ ed. Philadelphia: WB Saunders Company; 2010. H. 35-50.

5. Eales LJ. Immunology for life scientist. $2^{\text {nd }}$ ed. England: Wiley; 2003. H. 90, 216-224.

6. Sunardi C, Dewi PNL, Sutedja L, Kardono LBS. Studi aktivitas antimikroba minyak atsiri dari rimpang Kaemperia rotunda L., Curcuma zedoaria Rosc. dan Curcuma mangga Val. Et ZIJP. Dalam: Prosiding Seminar Nasional Tumbuhan Obat Indonesia XXI. Surabaya: 2728 Maret 2002.

7. Makanabe H, Maru N, Kuwabara A, Kamo T, Hirota M. Anti-inflammatory sesquiterpenes from Curcuma zedoaria, <http://findarticles. com/p/articles/_mi_qa4091/is_200501/ai_ n9474296. 2006> 18 Maret 2008.

8. Carvalho FR, Vassão RC, Nicoletti MA, Maria D, Carvalho FR. Effect of Curcuma zedoaria crude extract against tumor progression and immunomodulation. J Venom Anim Toxins incl Trop Dis. 2010; 16(2): 326-41.

9. Bugno A, Nicoletti MA, Almodóvar AAB, Pereira TC, Auricchio MT. Antimicrobial efficacy of Curcuma zedoaria extract as assessed by 
linear regression compared with commercial mouthrinses. Braz J Microbiol. 2007; 38(3): 427-32.

10. Kaushik ML, Jalalpure SS. Antiiflammatory efficacy of Curcuma zedoaria Rosc root extract. Asian J Pharm Clin Res. 2011; 4(3): 90-2.

11. Handajani J. Temu putih (Curcuma zedoaria Rosc., Zingiberaceae) volatile oil increased phagocytic activity of neutrophils exposed to A. actinomycetemcomitans. Proceeding The International Symposium on Oral and Dental Sciences, 17-18 Januari 2013.

12. Naz S, Jabeen S, Iyas S, Manzoor F, Aslam F, Al A. Antibacterial activity of Curcuma Longa varieties against different strains of bacteria. Pak J Bot 2010; 42(1): 455-62.

13. Handajani J. Minyak atsiri temu putih (Curcuma zedoaria Rosc., Zingiberaceae) menurunkan ekspresi $\mathrm{CD}^{+}$pada gingiva terpapar A. actinomycetemcomitans. Maj Ked $\mathrm{Gi}, 2013 ; 20(1):$ 9-12.

14. Handajani J. Efek opsonisasi serum terhadap aktivitas fagositosis sel makrofag terpapar aggregat bakteri $\mathrm{A}$. actinomycetemcomitans setelah pemberian minyak atsiri Temu Putih. Dentika Dent J. 2013; 17(3): 217-222.

15. Aberg $\mathrm{CH}$, Sjödin B, Lakio L, Pussinen PJ, Johansson A, Claesson R. Presence of Aggregatibacter actinomycetemcomitans in young individuals: a 16- year clinical and microbiological follow-up study. J Clin Periodontol. 2009; 36(10): 815-22.

16. Bio Research. Protocol for performing a trypan blue viability test technical reference guide <http://bio.lonza.com> 24 November 2012.

17. Fujiwara N, Kobayashi K. Macrophages in inflammation. Curr Drug Targets Inflamm Allergy. 2005; 4(3): 281-6.

18. Ren K, Torres R. Role of interleukin-1 $\beta$ during pain and inflammation. Brain Res Rev. 2009; 60(1): 57-64.

19. Jang MK, Lee HJ, Kim JS, Ryu JH. A curcuminoid and two sesquiterpenoids from Curcuma zedoaria as inhibitors of nitric oxide synthesis in activated macrophages. Arch Pharm Res. 2004; 27(12): 1220-5.

20. Tiemessen M, Kunzmann S, Schmidt-Weber C, Garssen J, Bruijnzeel-Koomen C, Knol E, van Hoffen E. Transforming growth factor-beta inhibits human antigen-specific CD4+ $\mathrm{T}$ cell proliferation without modulating the cytokine response. Int Immunol. 2003; 15(12): 1495504.

21. Seymour GJ, Taubman MA, Eastcott JW, Gemmell E, Smith DJ. CD29 expression on $\mathrm{CD}^{+}$gingival lymphocytes supports migration of activated memory $T$ lymphocytes to diseased periodontal tissue. Oral Microbiol Immunol. 1997; 12(3): 129-34. 